\title{
JUURNAL.RU
}

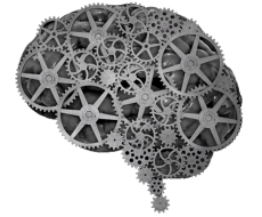

COMPANY GROUP "INTELLEKT"

\author{
Киселев В.В., Хохолов Ю.А. \\ Институт горного дела Севера им. Н.В.Черского СО РАН \\ Якутск, Россия
}

doi: 10.18411/1j2016-7-1-10

idsp 000001: 1j2016-16-1-10

\section{Подземный способ разработки природно-техногенных россыпных месторождений криолитозоны}

Аннотация: Предложен новый подземный способ разработки техногенных мерзлых россыпных месторождений. Представлены результаты расчетов продолжительности формирования ледяных закладочных массивов в отработанных россыпных шахтах Севера.

Ключевые слова: россыпная шахта, криолитозона, ледяной закладочный массив, послойное замораживание, природно-техногенные россыпи.

Общеизвестно, что на территориях золотодобывающих регионов азиатской части криолитозоны имеется большое количество отработанных россыпных шахт (РШ), где в процессе их первичной отработки были оставлены целики с высоким содержанием металла и прибортовые запасы некондиционных песков, которые в настоящее время перешли в разряд кондиционных [1].

Проведенными специалистами ВНИИ-1 и ИГДС исследованиями установлено [2], что из трех категорий техногенных россыпных месторождений криолитозоны, пригодных для вторичной отработки подземным способом, наиболее неблагоприятными являются ранее отработанные РШ с открытым выработанным пространством, т.е. незаполненным льдом или обрушенными породами. В этом случае в соответствии с ЕПБ требуется проведение целого комплекса подготовительных работ, включая предварительное крепление 
выработанного пространства, т.к. отработка даже одного целика может привести к полному обрушению кровли, что чревато горным ударом со всеми вытекающими негативными последствиями.

В связи с вышеизложенным, может быть рекомендован, по нашему мнению, поэтапный способ повторной отработки остаточно-целиковых песков, находящихся в ранее отработанных РШ. В этом случае по завершении подготовительных и разведочных работ все подземные горные работы должны вестись в целях обеспечения безопасности только в зимний период и поэтапно. Причем в первый год (I этап) должно быть произведено крепление или полная закладка выработанного пространства с консервацией РШ на летний период, а на следующий год (II этап) - вестись проходческие и очистные работы (также в зимний период).

Для разработки таких россыпей предлагается специальный способ (рис.1) [3], включающий предварительное возведение (в зимнее время) в открытом выработанном пространстве ранее отработанной РШ ледяного закладочного массива путем его послойного намораживания и вентилирования атмосферным воздухом, что обеспечивает высокую скорость возведения. В этих целях в зимний период с поверхности по всей площади отработанного шахтного поля пробуриваются сквозные вертикальные скважины диаметром 500-600 мм (до верхней границы техногенного пласта песков). Кроме этого, для нагнетания в выработанное пространство холодного атмосферного воздуха в границах отработанного шахтного поля также пробуриваются вентиляционные скважины такого же диаметра, а так же производится заготовка колотого льда, который складируется у загрузочных скважин. При достижении устойчивой

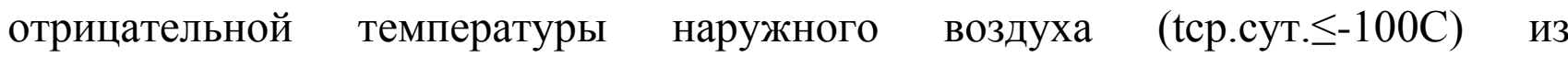
водохранилища по теплоизолированному трубопроводу насосом в загрузочные скважины вперемешку со льдом подается вода с образованием водо-ледяной смеси (соотношение твердой и жидкой фаз 1:3 по объему), которой заполняется все выработанное пространство РШ слоем расчетной толщины. 

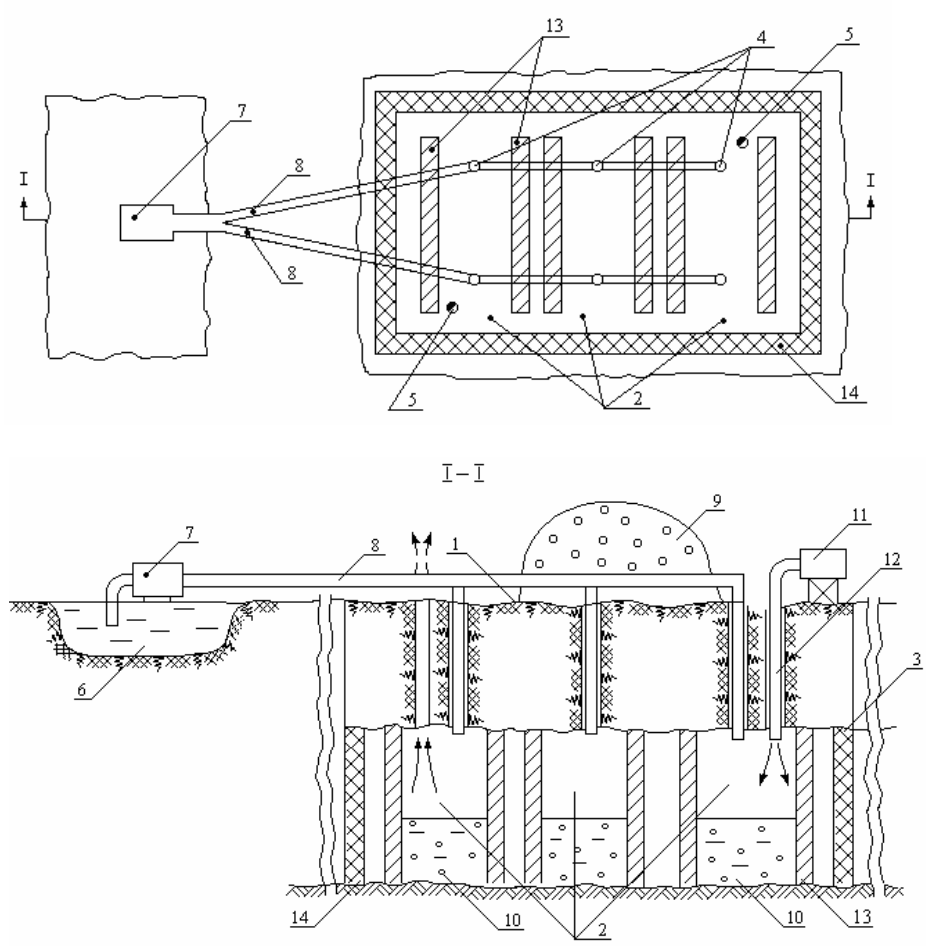

Рис. 1. Подземный способ разработки техногенных глубокопогребенных россыпных месторождений криолитозоны: 1 - земная поверхность; 2 - выработанное пространство отработанной россыпной шахты; 3 верхняя граница техногенного пласта песков; 4 - сквозные вертикальные скважины, предназначенные для подачи закладочной смеси (воды с колотым льдом); 5 - вентиляционные скважины; 6 - водохранилище; 7 водяной насос; 8 - водяной трубопровод; 9 - колотый лед; 10 - возведенный закладочный слой (водой ледяной); 11 - нагнетательный вентилятор; 12 -вентиляционный рукав; 13 -ленточные целики (подлежащие отработке); 14 - прибортовые техногенные пески.

По завершении этой операции закладочные скважины временно перекрывают и по вентиляционным скважинам с помощью нагнетающих вентиляторов по прорезиненным рукавам осуществляют продувку выработанного пространства холодным атмосферным воздухом до полного замерзания возведенного слоя водо-ледяной закладки (t $-100 \mathrm{C})$. После этого, с выполнением всех вышеописанных операций выкладывается (намораживается) второй слой ледового массива и так далее до полной закладки всего выработанного пространства РШ.

На летнее время заполненная льдом РШ консервируется, а в следующий зимний период (второй этап) отработка техногенных запасов производится по традиционной технологии [2]. 
По окончании всех видов проходческих работ производится отработка целиков и прибортовых запасов техногенных песков (обратным ходом). Вновь образованное выработанное пространство (на месте отработанных целиков) может быть по мере отработки техногенных песков также заложено льдом по вышеописанной технологии, при этом может быть использован лед, поднятый на поверхность во время ведения проходческих работ.

Следует отметить, что оптимизация формирования ледяной закладки состоит в минимизации времени послойного замораживания воды заливаемой в РШ и является нестационарной, нелинейной и многопараметрической задачей. На время замораживания единичного водного слоя влияет ряд факторов, которые необходимо учитывать в их взаимодействии. Это - объем и начальная температура заливаемой воды, длительность периода промораживания, температура и расход подаваемого наружного воздуха, естественная температура горного массива, требуемая температура возводимого ледяного закладочного массива. Только при оптимальном соотношении всех этих параметров возможно возвести монолитный ледовый искусственный массив с необходимыми прочностными свойствами за заданный период времени.

Для определения температурного поля ледяного закладочного и породного массивов разработана двухмерная математическая модель теплообмена рудничного воздуха с возводимой ледяной закладкой и окружающим массивом горных пород $[4,5]$.

В качестве примера, для оценки скорости возведения ледяного закладочного массива проведены расчеты при следующих исходных данных: высота отработанной камеры - 1,4 м, её длина соответствует ширине панели и равна 81 м, а ширина составляет 14 м, удельная теплоемкость пород 900 Дж/(кг·К), влажность $5 \%$, плотность скелета 2500 кг/м3, коэффициент теплопроводности мерзлых пород 2 Вт/(м·К); талых $-1,8$ Вт/(м·К); естественная температура пород $-1,5^{\circ} \mathrm{C}$, начальная температура заливаемой воды $+1^{\circ} \mathrm{C}$ 
На рисунке 2 приведены результаты расчета для случая, когда возведение ледового массива в РШ начинается с 1 декабря и при начальной температуре водяного слоя, равной $+1^{\circ} \mathrm{C}$. Из графиков видно, что для различной толщины слоя существует оптимальное время замораживания, при котором суммарная продолжительность формирования ледяного закладочного массива минимальна.

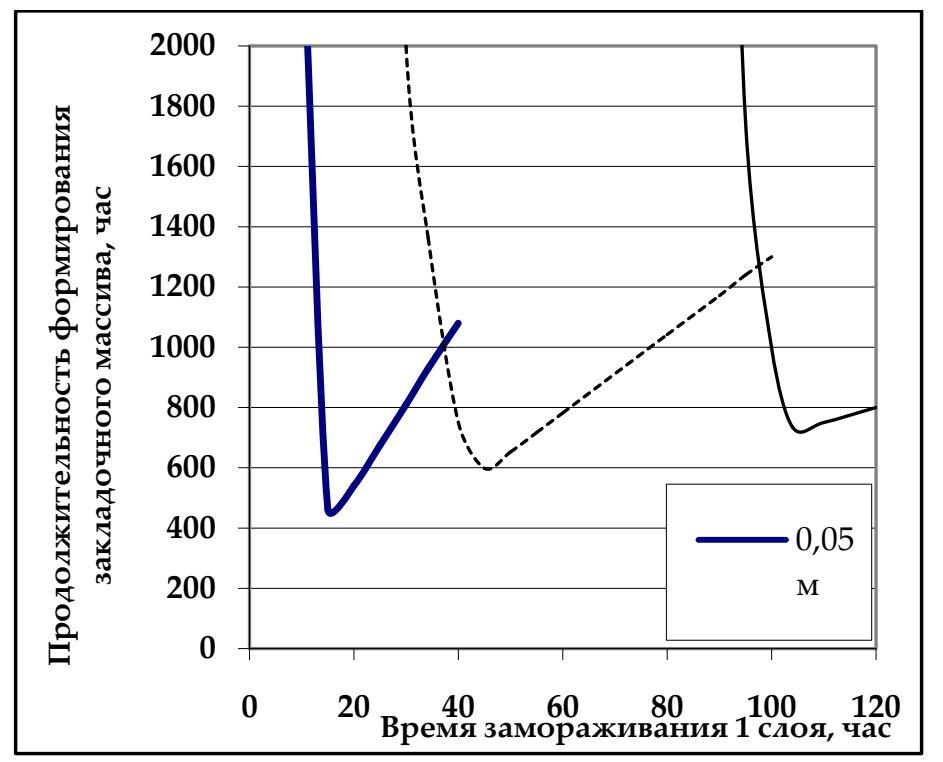

Рис. 2. Продолжительность формирования ледяного закладочного массива в РШ в зависимости от времени замораживания 1 слоя при различных толщинах.

Как видно из графиков, даже небольшое отклонение времени замораживания в сторону уменьшения ведет к резкому увеличению суммарной продолжительности формирования закладочного массива. Увеличение продолжительности проморозки каждого слоя пропорционально увеличивает общее время формирования закладки. Однако, несмотря на это, на практике продолжительность замораживания должна приниматься с некоторым запасом, чтобы гарантировать полное промораживание закладочного массива за заданный промежуток времени, исключая тем самым наличие непромерзших зон, что недопустимо.

По нашему мнению, предлагаемый способ имеет следующие преимущества: безопасность ведения подземных горных работ; дешевизна закладочного материала; невысокая трудоемкость возведения ледяных закладочных массивов; высокая механизация и скорость проходки скважин; 
низкие материальные затраты на производство закладочного материала (льда); высокая скорость ведения горных выработок, проходимых по льду; высокая скорость замораживания послойно возводимых ледяных закладочных массивов за счет использования высокопотенциального атмосферного холода; высокие компрессионные свойства возведенных ледяных закладочных массивов, обеспечивающих безопасность ведения подземных горных работ и целостность земной поверхности.

\section{Литература:}

1. Мамаев, Ю.А., Литвинцев В.С., Пономарчук Г.П. Техногенные россыпи благородных металлов Дальневосточного региона России и их рациональное освоение. - М.: Изд-во «Горная книга», 2010. - 309 с.

2. Шерстов, В.А., Скуба В.Н., Лубий К.И., Костромитинов К.Н. Подземная разработка россыпных месторождений Якутии. - Якутск: Кн. изд-во, 1981. $-182 \mathrm{c}$.

3. Патент RUS 2452858, МПК Е 21 C 41 22,E 21 F 15 00. Подземный способ разработки техногенных глубокопогребенных россыпных месторождений криолитозоны / В.В. Киселев, Ю.А. Хохолов; заявитель и патентообладатель ИГДС СО РАН. - № 2010127427/03; заявл. 02.07.2010; опубл. 10.06.2012, Бюл. № 16.

4. Каймонов М.В., Хохолов Ю.А., Курилко А.С., Необутов Г.П. Методика расчета послойного намораживания пород при формировании льдопородного массива в горных выработках // Горный информ.-аналит. бюллетень. - 2003. - № 9 - С. 47-49.

5. Хохолов, Ю.А., Мамонов А.Ф., Зубков В.П. Оптимизация формирования льдопородного массива в горных выработках // Горный информ.-аналит. бюллетень. - 2004. - № 10. - С. 103-106. 